\title{
Pengaruh Live-Chat dan E-WOM Terhadap Pengambilan Keputusan Transaksi Online pada Marketplace E-Commerce
}

\author{
Dira Fatrina, Insannul Kamil* dan Alizar Hasan \\ Jurusan Teknik Industri, Fakultas Teknik, Universitas Andalas, Kampus Limau Manis, Pauh, Padang 25163, Indonesia
}

\section{INFORMASI ARTIKEL}

Sejarah Artikel:

Diterima Redaksi: 15 Juli 2019

Revisi Akhir: 21 Oktober 2019

Diterbitkan Online: 04 Januari 2020

\section{KATA KUNCI}

\section{Live Chat,}

Electronics Word Of Mouth,

Perilaku penjual,

Structural Equation Modeling,

Partial Least Square

KORESPONDENSI

E-mail: ikamil@ft.unand.ac.id*

\section{A B S T R A C T}

Mengetahui faktor-faktor yang mempengaruhi konsumen untuk memutuskan membeli sebuah barang secara online adalah merupakan hal yang sangat krusial bagi pelaku usaha untuk mampu memenangkan persaingan antar pelaku usaha di situs e-commerce. Pada artikel ini, dipelajaripengaruh live chat dengan perilaku penjual sebagai variabel mediasi, dan Electronics Word Of Mouth (E-WOM) dengan kelompok rujukan sebagai variabel mediasi terhadap keputusan pembelian. Teknik yang digunakan dalam pengambilan sampel adalah non Probability dengan purposive sampling kemudian data diolah dengan menggunakan metoda Teknik Structural Equation Modeling (SEM) dengan Partial Least Square (PLS). Hasil studi menunjukkan bahwa live chat yang diharapkan mampu menjadi penghubung antarpenjual dan pembeli ternyata belum memiliki pengaruh yang signifikan terhadap keputusan pembelian, tetapi review dari pembelisebelumnya dengan memanfaatkan rekomendasi dari kelompok rujukan (selebriti) sebagai variabel mediasi dapat memberikan pengaruh yang signifikan terhadap keputusan pembelian calon pembeli.

\section{PENDAHULUAN}

Pesatnya perkembangan teknologi digital sangat mempengaruhi kehidupan ekonomi masyarakat terutama yang berkaitan dengan perdagangan melalui internet atau disebut dengan $E$-commerce yang terus tumbuh dan menjadi sangat popular. E-commerce memberikan pengalaman baru dalam berbelanja dan menawarkan harga yang lebih murah dibandingkan berbelanja secara konvensional. Selain itu, berbelanja melalui internet tidak dibatasi waktu dan wilayah sehingga bisa dilakukan kapan saja dan dimana saja. Tidak heran, jika perkembangan volume transaksi belanja online dari tahun ke tahun meningkat cukup tajam. Berdasarkan data, volume transaksi Global untuk Tahun 2017 adalah sebesar 2,3 T USD dan diprediksi tumbuh sekitar $21 \%$ ditahun 2018 menjadi 2,8 T USD [1].

Indonesia merupakan salah satu pangsa pasar terbesar produkproduk yang dipasarkan pada E-commerce karena besarnya jumlah pembeli digital Indonesia. Pada awal tahun 2018 pembeli digital Indonesia mencapai 31,6 juta pembeli atau sekitar $11,8 \%$ dari total populasi dengan volume penjualan ritel E-commerce mencapai Rp.117,7 T. Penjualan ritel E-commerce Indonesia merupakan yang terbesar di kawasan Asia Tenggara. Jumlah tersebut diproyeksikan akan meningkat menjadi 43,9 juta pembeli pada 2022 dengan penetrasi $15,7 \%$ dari jumlah penduduk Indonesia dengan volume transaksi sebesar 226,1T atau naik dua kali lipat [2]. Fakta tersebut menunjukkan bahwa bisnis $E$-commerce memang sangat prospektif.

Saat ini banyak bermunculan situs-situs yang mampu menghubungkan antara penjual dengan pembeli secara online yang biasa disebut dengan marketplace[3]. Hal ini akan mempermudah penjual dalam menggunakan situs tersebut untuk memasarkan produknya tanpa dibatasi jarak dan waktu. Tetapi, ketatnya persaingan di dalam marketplace memungkinkan satu produk dijual oleh beberapa penjual dengan harga yang bersaing. Oleh karena itu penjual harus mampu mengetahui faktor apa saja yang 
mempengaruhi keputusan konsumen dalam membeli barang untuk pertama kalinya pada sebuah marketplace.

Meskipun banyak keunggulan yang dimiliki oleh e-commerse namun masih terdapat beberapa kekurangan dibandingkan berbelanja secara konvensional, seperti pelanggan tidak bisa merasakan secara langsung barang yang ingin dibeli seperti baju atau sepatu. Ini bisa menimbulkan ketidakpastian dan keraguan bagi pembeli yang bisa mempengaruhi keputusan untuk berbelanja.

Beberapa usaha dilakukan untuk membantu konsumen dalam membuat keputusan ketika berbelanja secara online, diantaranya adalah dengan menambahkan fitur live chat pada marketplace untuk memfasilitasi komunikasi antara pembeli dengan penjual. Studi terdahulu telah menunjukkan bahwa penggunaanlive chat dapat memberikan pengaruh yang positif terhadap keputusan pembeli untuk berbelanja $[4,5,6]$. Perilaku penjual saat melakukan interaksi dengan konsumen melalui live chatmenjadi factor yang mempengaruhi keputusan pembelian [4]. Ini disebabkan karena dengan berinteraksi secara langsung dengan konsumen, penjual dapat memahami kebutuhan konsumen dan juga mampu menciptakan kedekatan hubungan secara personal diantara penjual dan pembeli, sehingga konsumen percaya bahwa produk yang dijual oleh toko tersebut sesuai dengan harapannya. Selain itu, penggunaan live chatakan meningkatkan keinginan pembeli untuk bertransaksi terutama jika reputasi penjual rendah dan harga barang murah [5]. Ini karena live chat mampu mengurangi resiko dari ketidakpastian terhadap kualitas barang yang akan dibeli melalui interaktivitas yang dirasakan secara langsung sehinggadapat mengurangi efek negatif dari ketidakpastidan produk [6]. Lebih lanjut lagi, komunikasi dua arah yang dilakukan antara konsumen dan penjual dapat meningkatkan kepercayaan, kepuasan dan keinginan konsumen untuk pembelian kembali [7, 8]. Meskipun studi terdahulu telah mengkaji hubungan antara live chat dengan keputusan pembelian, namun perlu dilakukan kajian agar pengaruh tersebut dapat diperbesar dengan memanfaatkan perilaku penjual sebagai variabel mediasi.

Di sampinglive chat, keputusan pembelian juga dipengaruhi oleh faktor sosial [9]. Bagi konsumen yang tidak memiliki pengalaman berbelanja pada sebuah toko online, mereka akan berupaya untuk mencari referensi atau rekomendasi dari lingkungannya $[10,11]$. Salah satu metode yang paling banyak digunakan dan berkembang pesat saat ini adalah melalui electronic word of mouth (E-WOM), yaitu suatu penyampaian pernyataan terhadap suatu produk atau perusahaan oleh konsumen kepada orang lain atau institusi dengan media internet [12].

Beberapa studi terdahulu telah menunjukkan hubungan antara $E$ WOM dengan keputusan pembelian konsumen. Bosman melakukan penelitian terkait kredibilitas reviewdari E-WOM pada marketplace[13]. Dari komunikasi review pada marketplace, diketahui bahwa rating yang diberikan, panjangnya testimoni, waktu penyampaian review dan marketplace sebagai tempat penyampaiannya memberikan pengaruh yang signifikan dan positif terhadap kredibilitas review itu sendiri [13] tetapi belum sampai pada pengaru E-WOM terhadap keputusan pembelian konsumen, sehingga perlu dilakukan kajian lebih lanjut.

Wang melaporkan bahwa rekomendasi dari seseorang yang memiliki hubungan kedekatan sosial yang cukup baik akan memberikan dampak yang positif dan signifikan terhadap keputusan pembelian, sebaliknya hubungan kedekatan sosial yang lemah akan memberikan dampak yang positif atau negatif terhadap informasi yang disampaikan oleh orang-orang yang memiliki kedekatan sosial yang kuat dengan calon pembeli [10]. Tetapi di dunia virtual, rekomendasi terhadap sebuah produk tidak hanya dapat diperoleh dari orang-orang terdekat saja, tapi bisa dari berbagai pihak yang mungkin tidak memiliki hubungan apa-apa dengan calon pembeli. Rekomendasi tersebut bisa berasal dari kelompok rujukan seperti keluarga, teman, tetangga, selebritis, dorongan ahli yang berpengalaman, the Common Man, dan juru bicara eksekutif [14].

Salah satu kelompok rujukan yang sering dijadikan sebagai referensi dalam penggunaan produk adalah selebritis. Saat ini banyak sekali anak-anak muda menjadikan selebritis sebagai panutan seperti gaya berpakaian, gaya hidup, hobi yang digandrungi sehingga banyak pelaku usaha yang melihat fenomena ini menjadi kesempatan untuk menjadikan selebriti sebagai model dari produk yang akan mereka tawarkan, dengan harapan hal tersebut dapat meningkatkan penjualan produk mereka [15].

Dalam artikel ini, kami mempelajari bagaimana pengaruh live chat dengan perilaku penjual sebagai variabel mediasi dan $E-W O M$ dengan kelompok rujukan sebagai variabel mediasi terhadap keputusan pembelian. Tujuannnya adalah untuk mengetahui dan menganalisis hubungan antara live chat dengan keputusan pembelian dengan variabel mediasi berupa perilaku penjual dan hubungan antara $E-W O M$ dengan keputusan pembelian dengan variabel mediasi berupa Kelompok Rujukan. Di sini, variabel perilaku penjual dijadikan sebagai variabel mediasi yang diharapkan bisa memperbesar pengaruh variabel live chatterhadap keputusan pembelian. Disamping itu, selebriti dijadikan sebagai kelompok rujukan yang mampu meningkatkan pengaruh siginifikan E-WOM (review konsumen) terhadap keputusan pembelian konsumen (variabel mediasi).

\section{METODE}

\subsection{Perancangan Hipotesis}

Untuk mencapai tujuan dari penelitian ini, dibangun beberapa hipotesis mengenai pengaruh live chat terhadap keputusan pembelian dan perilaku penjual sebagai variable mediasi, serta hubungan antara kedua variable tersebut. Selain itu, dinyatakan juga hipotesis mengenai pengaruh E-WOMterhadap keputusan pembelian dengan menggunakan kelompok rujukan sebagai variable mediasi. Berikut pernyataan hipotesis dalam penelitian ini:

Kalimat Hipotesis pertama 
$\mathbf{H}_{\mathbf{0}}$ :Live chat tidak berpengaruh signifikan terhadap keputusan pembelian

$\mathbf{H}_{1}$ :Live chat berpengaruh signifikan terhadap keputusan pembelian $[4,5,6]$.

Kalimat Hipotesis kedua

$\mathbf{H}_{\mathbf{0}}$ : Live chat tidak berpengaruh signifikan terhadap perilaku penjual

$\mathbf{H}_{1}$ :Live chat berpengaruh signifikan terhadap perilaku penjual

Kalimat Hipotesis ketiga

$\mathbf{H}_{\mathbf{0}}$ :Perilaku penjual tidak berpengaruh signifikan terhadap keputusan pembelian

$\mathbf{H}_{1}$ :Perilaku penjual berpengaruh signifikan terhadap keputusan pembelian [4]

Kalimat Hipotesis keempat

$\mathbf{H}_{\mathbf{0}}$ :Live chat tidak berpengaruh signifikan terhadap keputusan pembelian dengan perilaku penjual sebagai variabel mediasi

$\mathbf{H}_{1}$ :Live chat berpengaruh signifikan terhadap keputusan pembelian dengan perilaku penjual sebagai vaiabel mediasi

Kalimat Hipotesis kelima

$\mathbf{H}_{\mathbf{0}}: E-W O M$ tidak berpengaruh signifikan terhadap keputusan pembelian

$\mathbf{H}_{1}: E-W O M$ berpengaruh signifikan terhadap keputusan pembelian

Kalimat Hipotesis keenam

$\mathbf{H}_{\mathbf{0}}: E-W O M$ tidak berpengaruh signifikan terhadap kelompok rujukan

$\mathbf{H}_{1}: E-W O M$ berpengaruh signifikan terhadap kelompok rujukan [10]

Kalimat Hipotesis ketujuh

$\mathbf{H}_{\mathbf{0}}$ :Kelompok rujukan tidak berpengaruh signifikan terhadap keputusan pembelian

$\mathbf{H}_{1}$ :Kelompok rujukan berpengaruh signifikan terhadap keputusan pembelian [10][14]

Kalimat Hipotesis kedelapan

$\mathbf{H}_{\mathbf{0}}: E-W O M$ tidak berpengaruh signifikan terhadap keputusan pembelian dengan kelompok rujukan sebagai vaiabel mediasi

$\mathbf{H}_{1}: E-W O M$ berpengaruh signifikan terhadap keputusan pembelian dengan kelompok rujukan sebagai vaiabel mediasi

\subsection{Perancangan populasi dan sampel}

Pada penelitian ini, populasi yang digunakan adalah semua pengguna internet yang pernah memiliki pengalaman berbelanja online di situs marketplace di Indonesia. Pengambilan sampel dilakukan dengan sampling dengan menggunakan teknik purposive sampling dan disebarkan secara online via google forms. Sedangkan sampelnya maximal 50 koresponden untuk setiap konsumen situs marketplace yang terbesar di Indonesia yaitu Lazada, Tokopedia, Bukalapak, Blibli dan Shopee.

Skala pengukuran likert digunakan untuk menyatakan setuju atau ketidak setujuan terhadap subjek, objek, atau kejadian tertentu. Setiap pertanyaan disusun sedemikian rupa agar bisa dijawab dalam 5 (Lima) dan 9 (Sembilan) tingkat jawaban atas pernyataan yang diajukan dengan urutan sebagai berikut:
Tabel 1. Skala Penilaian Pada Kuisioner

\begin{tabular}{ll}
\hline $\begin{array}{c}\text { Klasifikasi } 9 \text { tingkatan } \\
\text { jawaban }\end{array}$ & $\begin{array}{c}\text { Klasifikasi } 5 \text { tingkatan } \\
\text { jawaban }\end{array}$ \\
\hline Sangat Berpengaruh (SB) & Tidak Pernah $=0$ \\
Diantara SB-TB & Pernah $=1$ \\
Tidak Berpengaruh (TB) & Kadang-kadang $=2$ \\
Diantara TB-BS & Sering $=3$ \\
Biasa Saja (BS) & Sangat Sering $>3$ \\
Diantara BS-B & \\
Berpengaruh (B) & \\
Diantara B-SB & \\
Sangat Berpengaruh (SB) & \\
\hline
\end{tabular}

Semua pertanyaan pada umumnya menggunakan 9 (Sembilan) tingkat jawaban, diharapkan semakin mendekati jawaban yang ingin disampaikan oleh koresponden. Sementara untuk 5 (lima tingkatan hanya digunakan untuk pembelian berulang dan merekomendasikan ke orang lain yang merupakan elemen variabel keputusan konsumen.

Untuk pengolahan data, digunakan teknik Structural Equation Modeling (SEM) dengan Partial Least Square (PLS) karena dapat menganalisis banyak variabel respon serta explanatori sekaligus dan bersifat robust (kebal) [16].

\subsection{Perancangan Model Pengukuran (Outer Model)}

Model ini digunakan untuk mengetahui validitas dan reliabilitas yang menghubungkan indikator dengan variabel latennya. Indikator dalam penelitian ini adalah formatif. Berikut adalah Outer Model dari 5 (lima) variabel yang digunakan:

Tabel 2. Outer Model dari Variabel yang Digunakan

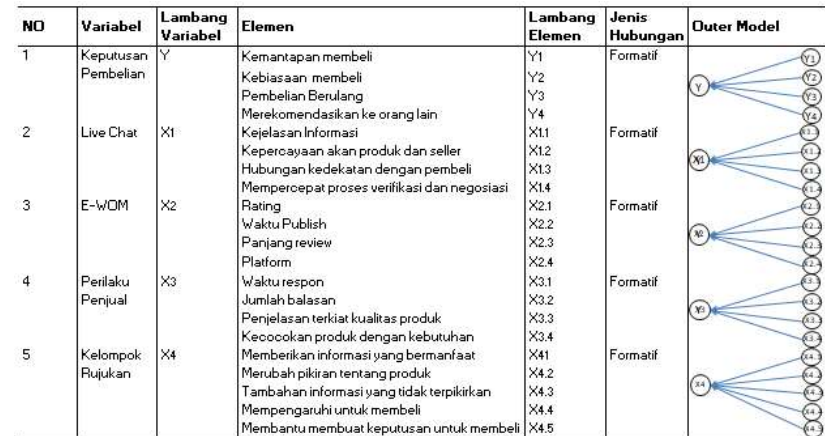

\subsection{Perancangan Model Struktural (Inner Model) dan Diagram Jalur}

Perancangan Model Struktural hubungan antar variabel laten didasarkan pada rumusan masalah atau hipotesis penelitian, pada penelitian ini terdapat 6 bentuk Inner Model yang menggambarkan 8 hipotesis sebelumnya. Kemudian dari keenam inner model yang telah ada dibuat diagram jalur dari penelitian. Diagram jalur memperlihatkan hubungan pola hubungan antar variable yang 
diteliliti. Dalam SEM pola hubungan diisi dengan variable yang diobservasi, variable laten dan indikatornya. Pada penelitian ini, diagram jalurnya dapat dilihat pada Gambar 1 .

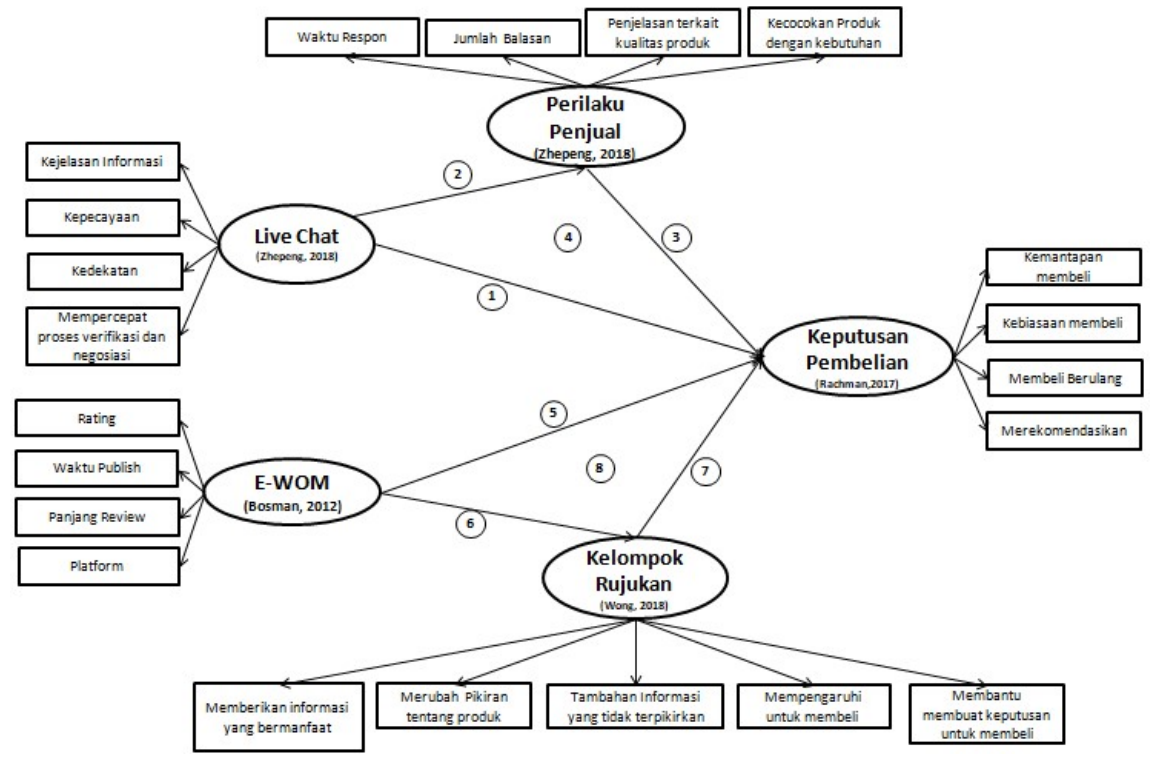

Gambar 1. Diagram jalur hubungan antar variabel

Setelah membangun diagram jalur, maka langkah selanjutnya adalah mengkonversi diagram ke dalam bentuk persamaan. Hasil pengolahan data menggunakan Smart PLS 3.2.1 kemudian dianalisis dengan teknik Evaluasi Goodness of fit untuk memvalidasi model secara keseluruhan dan Uji Hipotesis (Resampling Bootstraping) dengan tingkat kepercayaan 95\%.

\section{HASIL}

Jumlah korensponden yang mengisi kuisioner adalah 350 orang, yang terdiri dari $55 \%$ berjenis kelamin perempuan dan $45 \%$ berjenis kelamin laki-laki. Umur koresponden berkisar 19-64 tahun. Total koresponden yang pernah memiliki pengalaman berbelanja online via marketplace adalah $92,9 \%$ atau 325 koresponden dengan komposisi yang tidak merata diantara kelima situs marketplace yang dijadikan objek penelitian yaitu Shopee 44,2\%, Lazada 18,8\%, Tokopedia 16,8\%, Bukalapak 7,7\% dan Blibli 1,6\% sehingga data yang digunakan adalah 182 koresponden dengan komposisi sebagai berikut; konsumen Shopee, Lazada dan Tokopedia masing-masing 50 koresponden, Bukalapak 26 koresponden dan Blibli 6 koresponden.

Hasil pengukuran penelitian untuk masing-masing indikator dapat dilihat pada tabel 3 untuk skala penelitian 9 tingkatan dan tabel 4 untuk skala penelitian 5 tingkatan.
Tabel 3. Hasil Skala 9 Penilaian Pada Kuisioner

\begin{tabular}{|c|c|c|c|c|c|c|c|c|c|c|c|}
\hline \multirow{2}{*}{ Variabel } & \multirow{2}{*}{ Indikator } & \multicolumn{9}{|c|}{ Skala Penelitian } & \multirow{2}{*}{ Total } \\
\hline & & 1 & 2 & 3 & 4 & 5 & 6 & 7 & 8 & 9 & \\
\hline E-IWOM & 1 & 13 & 18 & 11 & 2 & 5 & 6 & 36 & 19 & 72 & 182 \\
\hline (Review & 2 & 14 & 20 & 9 & 1 & 2 & 2 & 31 & 15 & 88 & 182 \\
\hline \multirow[t]{2}{*}{ Konsumen) } & 3 & 14 & 19 & 11 & 1 & 4 & 5 & 31 & 14 & 83 & 182 \\
\hline & 4 & 10 & 25 & 10 & 2 & 10 & 9 & 43 & 23 & 50 & 182 \\
\hline Keputusan & 1 & 12 & 28 & 8 & 3 & 6 & 9 & 46 & 12 & 58 & 182 \\
\hline \multirow[t]{6}{*}{ Pembelian } & & 13 & 23 & 8 & 3 & 3 & 7 & 50 & 15 & 60 & 182 \\
\hline & & 15 & 25 & 5 & 1 & 1 & 5 & 42 & 16 & 72 & 182 \\
\hline & & 12 & 23 & 41 & 3 & 52 & 20 & 11 & 10 & 10 & 182 \\
\hline & 2 & 10 & 26 & 11 & 4 & 8 & 9 & 49 & 14 & 51 & 182 \\
\hline & & 10 & 27 & 7 & 1 & 1 & 0 & 50 & 14 & 72 & 182 \\
\hline & & 11 & 24 & 34 & 6 & 47 & 24 & 17 & 6 & 13 & 182 \\
\hline Kelompok & 1 & 14 & 29 & 23 & 6 & 32 & 10 & 24 & 12 & 32 & 182 \\
\hline \multirow{4}{*}{ Rujukan } & 2 & 19 & 25 & 34 & 6 & 46 & 23 & 12 & 13 & 4 & 182 \\
\hline & 3 & 12 & 24 & 29 & 6 & 28 & 27 & 30 & 10 & 16 & 182 \\
\hline & 4 & 9 & 30 & 25 & 9 & 42 & 12 & 23 & 14 & 18 & 182 \\
\hline & 5 & 13 & 28 & 25 & 8 & 52 & 9 & 20 & 14 & 13 & 182 \\
\hline \multirow[t]{4}{*}{ Live Chat } & 1 & 19 & 35 & 9 & 4 & 11 & 12 & 49 & 0 & 43 & 182 \\
\hline & 2 & 20 & 30 & 13 & 6 & 10 & 10 & 48 & 0 & 45 & 182 \\
\hline & 3 & 19 & 34 & 23 & 8 & 28 & 14 & 38 & 0 & 18 & 182 \\
\hline & 4 & 21 & 30 & 11 & 5 & 11 & 9 & 46 & 0 & 49 & 182 \\
\hline Perilaku & 1 & 16 & 25 & 8 & 2 & 6 & 5 & 47 & 11 & 62 & 182 \\
\hline \multirow[t]{3}{*}{ Penjual } & 2 & 12 & 25 & 20 & 5 & 20 & 19 & 31 & 17 & 33 & 182 \\
\hline & 3 & 15 & 23 & 11 & 3 & 3 & 3 & 33 & 12 & 79 & 182 \\
\hline & 4 & 14 & 24 & 11 & 3 & 4 & 2 & 36 & 11 & 77 & 182 \\
\hline
\end{tabular}

Tabel 4. Hasil Skala 5 Penilaian Pada Kuisioner 


\begin{tabular}{llcccccc}
\hline \multirow{2}{*}{ Variabel } & \multirow{2}{*}{ Indikator } & \multicolumn{4}{c}{ Skala Penelitian } & \multirow{2}{*}{ Tota } \\
\cline { 3 - 6 } & & $\mathbf{1}$ & $\mathbf{2}$ & $\mathbf{3}$ & $\mathbf{4}$ & $\mathbf{5}$ & $\mathbf{1}$ \\
\hline Keputusa & & 0 & 64 & 71 & 47 & 0 & 182 \\
n & 3 & 23 & 65 & 72 & 22 & 0 & 182
\end{tabular}

Data yang telah terkumpul kemudian diolah menggunakansoftware Smart PLS 3.2.1 dan menghasilkan outer model ditunjukkan oleh Gambar 2.

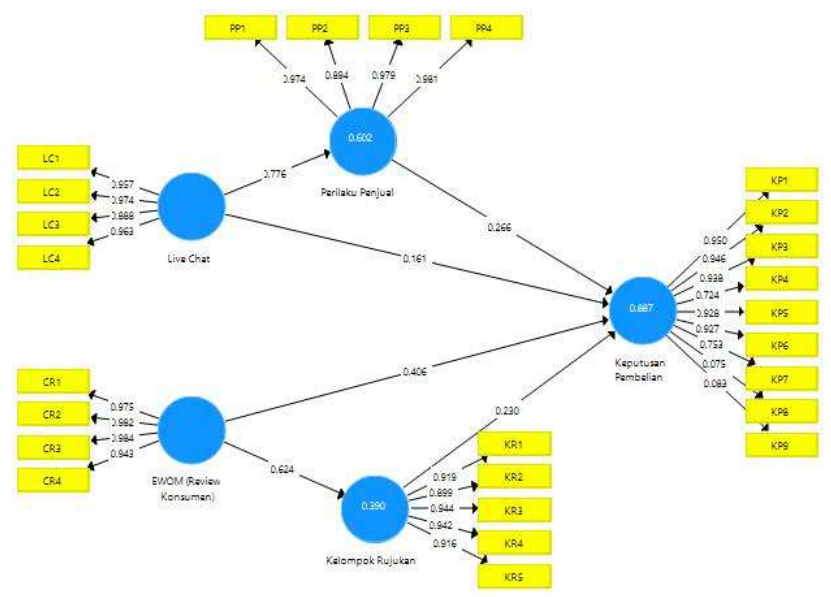

Gambar 2. Outer Model dari output Smart PLS 3.2.1

\subsection{Evaluasi Outer Model}

\subsubsection{Uji Convergent Validity}

Untuk menguji Convergen Validity digunakan nilai outer loading atau loading factor. Memenuhi jika nilainya $>0,7$. Dari Gambar 2diketahui terdapat 2 indikator yang memiliki outer loading $<0,7$ yaitu indikator K8 (merekomendasikan toko ke orang lain) dan indikator K9 (pembelian berulang) pada variabel keputusan pembelian dengan nilai 0,075 untuk K8 dan 0,083 untuk K9. Sehingga harus dilakukan eliminasi indikator satu per satu sehingga didapatkan nilai outer model $>0,7$. Gambar 3 memperlihatkan nilai outer model dengan semua indikator memiliki nilai $>0,7$.

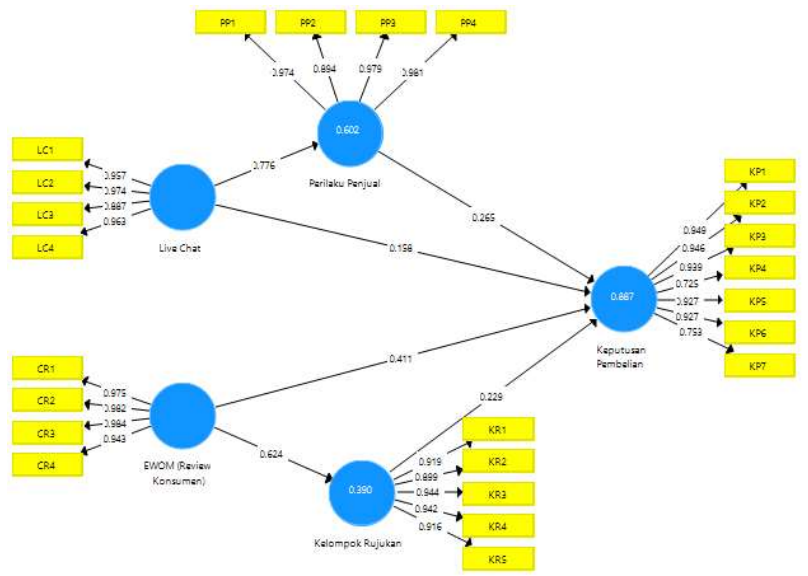

Gambar 3. Outer Model setelah indikator K8 dan K9 dieliminasi

\subsubsection{Uji Discriminant Validity}

Uji discriminant validity dilakukan menggunakan nilai cross loading. Suatu indikator dinyatakan memenuhi discriminant validity apabila nilai cross loading indikator pada variabelnya adalah yang terbesar dibandingkan pada variabel lainnya. Tabel 3 menunjukkan nilai cross loading untuk masing-masing indikator.

Tabel 3. Nilai Cross Loading Masing-masing Indikator

\begin{tabular}{|c|c|c|c|c|c|}
\hline & $\begin{array}{c}\text { EWOM } \\
\text { (ConsumenRe } \\
\text { view) }\end{array}$ & $\begin{array}{c}\text { Kelompok } \\
\text { Rujukan }\end{array}$ & $\begin{array}{l}\text { Keputusan } \\
\text { Pembelian }\end{array}$ & $\begin{array}{l}\text { Live } \\
\text { Chat }\end{array}$ & $\begin{array}{c}\text { Perilaku } \\
\text { Penjual }\end{array}$ \\
\hline$\overline{\mathrm{CR} 1}$ & 0.975 & 0.618 & 0.878 & 0.705 & 0.801 \\
\hline CR2 & 0.982 & 0.599 & 0.880 & 0.697 & 0.811 \\
\hline CR3 & 0.984 & 0.600 & 0.853 & 0.678 & 0.795 \\
\hline CR4 & 0.943 & 0.607 & 0.803 & 0.615 & 0.760 \\
\hline KP1 & 0.810 & 0.703 & 0.949 & 0.768 & 0.866 \\
\hline KP2 & 0.863 & 0.641 & 0.946 & 0.760 & 0.880 \\
\hline KP3 & 0.888 & 0.646 & 0.939 & 0.727 & 0.826 \\
\hline KP4 & 0.515 & 0.711 & 0.725 & 0.526 & 0.551 \\
\hline KP5 & 0.810 & 0.673 & 0.927 & 0.783 & 0.841 \\
\hline KP6 & 0.907 & 0.642 & 0.927 & 0.722 & 0.801 \\
\hline KP7 & 0.571 & 0.680 & 0.753 & 0.520 & 0.543 \\
\hline KR1 & 0.586 & 0.919 & 0.663 & 0.569 & 0.599 \\
\hline $\mathrm{KR} 2$ & 0.486 & 0.899 & 0.647 & 0.482 & 0.527 \\
\hline KR3 & 0.610 & 0.944 & 0.731 & 0.561 & 0.628 \\
\hline KR4 & 0.613 & 0.942 & 0.710 & 0.581 & 0.618 \\
\hline KR5 & 0.578 & 0.916 & 0.702 & 0.537 & 0.583 \\
\hline LC1 & 0.675 & 0.528 & 0.742 & 0.957 & 0.744 \\
\hline LC2 & 0.686 & 0.597 & 0.759 & 0.974 & 0.734 \\
\hline LC3 & 0.578 & 0.544 & 0.706 & 0.887 & 0.715 \\
\hline LC4 & 0.683 & 0.570 & 0.760 & 0.963 & 0.741 \\
\hline PP1 & 0.796 & 0.618 & 0.868 & 0.778 & 0.974 \\
\hline PP2 & 0.691 & 0.547 & 0.707 & 0.637 & 0.894 \\
\hline PP3 & 0.813 & 0.650 & 0.864 & 0.774 & 0.979 \\
\hline PP4 & 0.816 & 0.636 & 0.876 & 0.769 & 0.981 \\
\hline
\end{tabular}

Berdasarkan sajian data pada Tabel 3 dapat diketahui bahwa masing-masing indikator pada variabel penelitian memiliki nilai cross loading terbesar pada variabel yang dibentuknya dibandingkan dengan nilai cross loading pada variabel lainnya. Berdasarkan hasil yang diperoleh tersebut, dapat dinyatakan bahwa indikator-indikator yang digunakan dalam penelitian ini telah memiliki discriminant validity yang baik dalam menyusun variabelnya masing-masing.

Selain mengamati nilai cross loading, discriminant validity juga dapat diketahui melalui metode lainnya yaitu dengan melihat nilai average variant extracted (AVE) yang mana untuk masing-masing 
indikator dipersyaratkan nilainya harus $>0,5$ untuk model yang baik. Nilai AVE masing-masing indikator ditunjukkan oleh Gambar 4.

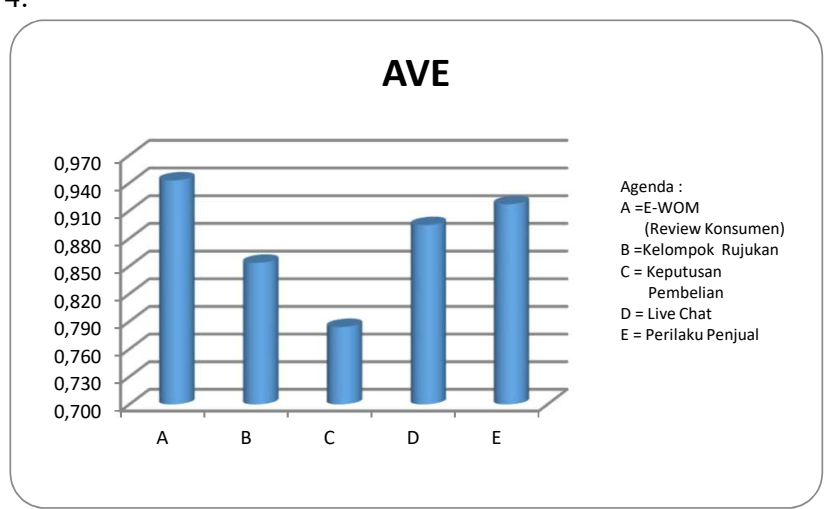

Gambar 4.Average Variant Extracted (AVE)

Berdasarkan sajian data dalam Gambar 4, diketahui bahwa nilai AVE untuk semua variabel yang diteliti $>0,5$. Dengan demikian dapat dinyatakan bahwa setiap variabel telah memiliki discriminant validity yang baik.

\subsubsection{Uji Composite Reliability}

Composite Reliability merupakan bagian yang digunakan untuk menguji nilai reliabilitas indikator-indikator pada suatu variabel. Suatu variabel dapat dinyatakan memenuhi composite reliability apabila memiliki nilai composite reliability $>0,7$

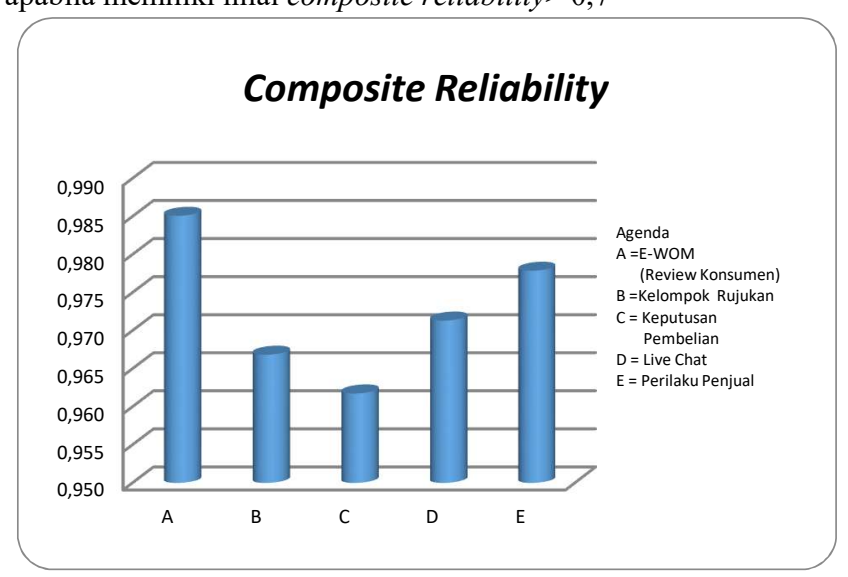

Gambar 5. Nilai Composite Reliability

Dari data dapat dilihat bahwa masing-masing variabel memiliki tingkat reliabilitas yang tinggi.

\subsubsection{Uji Cronbachs Alpha}

Uji realibilitas dengan composite reability di atas dapat diperkuat dengan menggunakan nilai cronbachs alpha. Suatu variabel dapat dinyatakan reliabel atau memenuhi cronbach alpha apabila memiliki nilai cronbach alpha $>0,7$. Nilai cronbach alpha untuk masing-masing variabel ditunjukkan oleh Gambar 6.

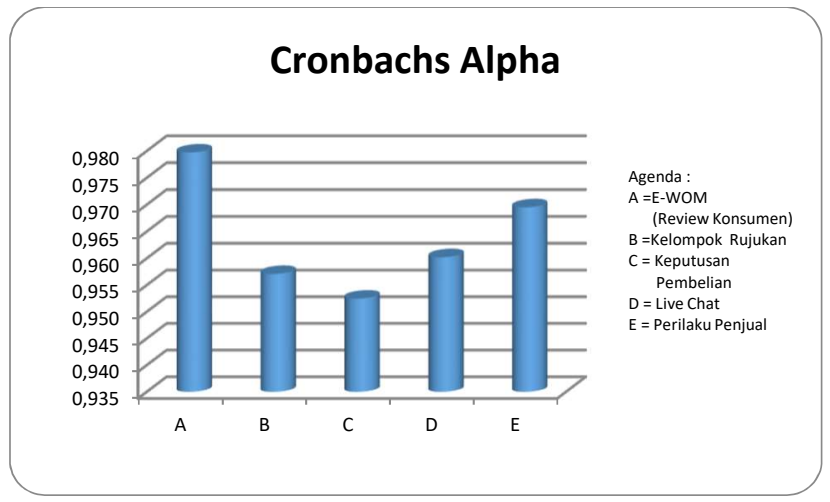

Gambar 6. Nilai Cronbachs Alpha setiap variabel

Berdasarkan sajian data pada Gambar 6, dapat diketahui bahwa nilai cronbach alpha dari masing-masing variabel penelitian $>0,7$. Dengan demikian hasil ini dapat menunjukkan bahwa masingmasing variabel penelitian telah memenuhi persyaratan nilai cronbach alpha, sehingga dapat disimpulkan bahwa keseluruhan variabel memiliki tingkat reliabilitas yang tinggi.

\subsection{Evaluasi Inner Model}

Evalauasi terhadap Inner Model dilakukan denganmenggunakan uji coefficient determination, uji goodness of fit dan uji hipotesis.

\subsubsection{Uji Coefficient Determination}

Uji coefficient determination (R-Square) digunakan untuk mengukur seberapa banyak variabel endogen dipengaruhi oleh variabel lainnya. Jika hasil $\mathrm{R}^{2}$ sebesar 0,67 ke atas untuk variabel laten endogen dalam model struktural mengindikasikan pengaruh variabel eksogen (yang mempengaruhi) terhadap variabel endogen (yang dipengaruhi) termasuk dalam kategori baik. Sedangkan jika hasilnya sebesar 0,33-0,67 maka termasuk dalam kategori sedang, dan jika hasilnya sebesar $0,19-0,33$ maka termasuk dalam kategori lemah.

Tabel 4. Nilai R-Square untuk Variabel-Variabel Dependen

\begin{tabular}{lcl}
\hline & R Square & \multicolumn{1}{c}{ Kategori } \\
\hline Kelompok Rujukan & 0.39 & Sedang \\
Keputusan Pembelian & 0.89 & Kuat \\
Perilaku Penjual & 0.60 & Sedang \\
\hline
\end{tabular}

Berdasarkan data yang diperoleh, diketahui bahwa 1 variabel dependent termasuk ke dalam kategori kuat, sementara yang lainnya masuk ke dalam kategori sedang. Inner Model ini dapat diterima dikarenakan hanya memiliki 2 variabel dependen yang masuk ke dalam kategori sedang [16].

\subsubsection{Uji Goodness of fit}

Penilaian goodness of fit diketahui dari nilai $Q$-Square. Nilai $Q-$ Square memiliki arti yang sama dengan coefficient determination ( $R$-Square) pada analisis regresi, dimana semakin tinggi $Q$-Square, maka model dapat dikatakan semakin baik atau semakin fit dengan 
data. Adapun hasil perhitungan nilai $Q$-Square adalah sebagai berikut:

$$
\begin{aligned}
\text { Q-Square } & =1-[(1-R 21) \times(1-R 22)] \\
& =1-[(1-0,39) \times(1-0,89) \times(1-0,60)] \\
& =1-0,02684 \\
& =0,97
\end{aligned}
$$

Berdasarkan hasil perhitungan di atas, diperoleh nilai Q-Square sebesar 0,97 . Hal ini menunjukkan besarnya keragaman dari data penelitian yang dapat dijelaskan oleh model penelitian adalah sebesar $97 \%$. Sedangkan sisanya sebesar 3\% dijelaskan oleh faktor lain yang berada di luar model penelitian ini. Dengan demikian, dari hasil tersebut maka model penelitian ini dapat dinyatakan telah memiliki goodness of fit yang baik.

\subsubsection{Uji Hipotesis}

Berdasarkan olah data yang telah dilakukan, hasilnya dapat digunakan untuk menjawab hipotesis pada penelitian ini. Uji hipotesis pada penelitian ini dilakukan dengan melihat nilai $T$ Statistics dan nilai $P$-Values. Hipotesis penelitian dapat dinyatakan diterima apabila nilai $P$-Values $<0,05$ atau T Statistik $<1,96$ (Tolak $\boldsymbol{H}_{\boldsymbol{0}}$ ). Tabel 5 menunjukkan hasil uji hipotesis yang diperoleh dalam penelitian ini melalui inner model.

Tabel 5.T-Statistics dan P-Values

\begin{tabular}{llcll}
\hline Hipotesis & Pengaruh & T Statistics & P Values & Hasil \\
\hline H1 & $\begin{array}{l}\text { Live Chat } \rightarrow \text { Keputusan } \\
\text { Pembelian }\end{array}$ & 1.367 & 0.172 & Ditolak \\
H2 & $\begin{array}{l}\text { Live Chat } \rightarrow \text { Perilaku } \\
\text { Penjual }\end{array}$ & 3.738 & 0.000 & Diterima \\
H3 & $\begin{array}{l}\text { Perilaku Penjual } \rightarrow \\
\text { Keputusan Pembelian }\end{array}$ & 1.374 & 0.170 & Ditolak \\
H4 & $\begin{array}{l}\text { Kelompok Rujukan } \rightarrow \\
\text { Keputusan Pembelian }\end{array}$ & 2.316 & 0.021 & Diterima \\
H5 & $\begin{array}{l}\text { EWOM (Customer } \\
\text { Reviews) } \rightarrow \text { Kelompok } \\
\text { Rujukan }\end{array}$ & 3.911 & 0.000 & Diterima \\
Kelompok Rujukan $\rightarrow$ \\
Keputusan Pembelian
\end{tabular}

Berdasarkan Tabel 5 dapat diketahui bahwa dua hipotesis ditolak yaitu pengaruh Live chat terhadap keputusan pembelian dengan pengaruh perilaku penjual terhadap keputusan pembelian karena memiliki nilai $P$-Values $>0,05$. Sehingga dapat dinyatakan hanya variabel $E-W O M$ yang memiliki pengaruh signifikan terhadap variabel keputusan pembelian.

Hal ini juga dapat dilihat pada Gambar 7 yang memperlihatkan bahwa hubungan antara variabel $E$-WOM memiliki hubungan yang sangat signifikan terhadap keputusan pembelian, dapat ditunjukkan dengan adanya penebalan garis pada inner model hasil boostrapping.

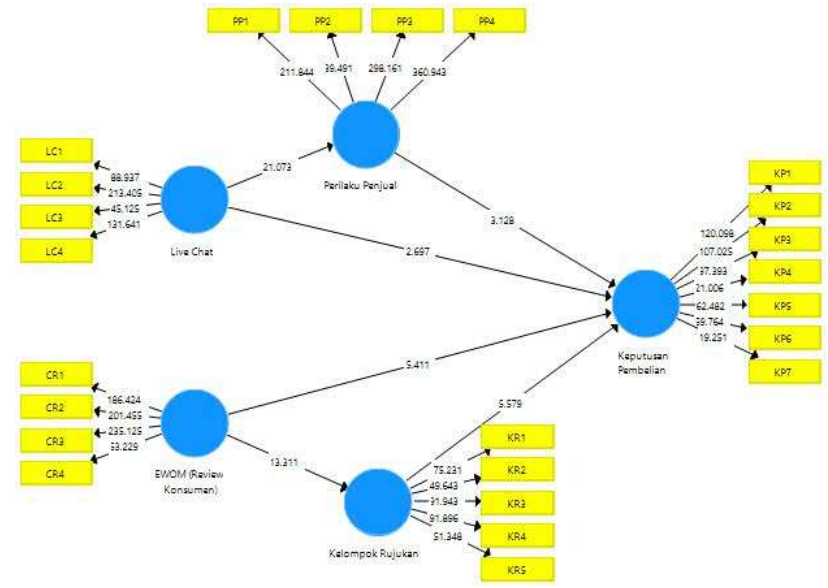

Gambar 7. Inner Model

\subsection{Evaluasi Pengaruh Tidak Langsung}

Proses evaluasi pengaruh tidak langsung hanya dihitung untuk hubungan antara variabel Kelompok Rujukan terhadap E-WOM dengan keputusan pembelian dikarenakan hubungan antara live chat tidak sigifikan terhadap variabel keputusn pembelian begitu juga halnya dengan perilaku penjual dengan keputusan pembelian.Untuk mengetahui apakah variabel perilaku penjual bertindak sebagai variabel mediasi diantara variabel live chat dengan keputusan pembelian, begitu juga dengan variabel Kelompok Rujukan terhadap $E$-WOM dengan keputusan pembelian, maka dihitung nilai Relative Size atau Variance Account Relative (VAR) :

$$
\begin{aligned}
V A R=\frac{a b}{a b+c} & =\frac{13,311 \times 5,579}{(13,311 \times 5,579)+5,441} \\
& =0,933 \text { (kuat) }
\end{aligned}
$$

\section{PEMBAHASAN}

Setelah dilakukan uji hipotesis diperoleh tiga hipotesis yang ditolak dan lima yang diterima dengan analisis sebagai berikut :

Hipotesis Pertama yang menyatakan bahwa Live chat memiliki pengaruh yang signifikan terhadap keputusan pembelian ditolak. Hal ini dapat disebabkan karena :

i. Tidak adanya jaminan bahwa barang yang diinginkan akan dikirim sesuai dengan hasil chatting dengan penjual. Pada transaksi di marketplace, situs marketplace memberikan kelonggaran waktu bagi pembeli untuk melakukan pembayaran tagihan. Rata-rata E-commerce di Indonesia memberikan waktu tenggat min 1x24 Jam. Dalam jeda waktu tersebut, si penjual dapat menjual barang tersebut ke orang lain yang telah melakukan pembayaran. Hal ini dilakukan oleh penjual untuk meminimalisir resiko gagal bayar dari pembeli sebelumnya.

ii. Barang fashion khususnya untuk produk dengan disain yang exclusive dan unlimited cenderung bersifat fast moving, sehingga pembeli cenderung memiliki perasaaan khawatir stok habis, seperti label vanilahijab, button scraf, talullah fashion look, dan sebagainya. Apalagi produk ini memiliki jadwal penjualan yang ketat dan secara berkala mengeluarkan 
produk-produk baru. Berbeda dengan hasil penelitian sebelumnya (ref [4]) yang meneliti produk skincare. Setiap orang memiliki tipe kulit yang berbeda, sehingga membutuhkan kosultasi terlebih dahulu sebelum memutuskan untuk membeli produk tersebut.

Hipotesis Kedua yang menyatakan bahwa Live chat memiliki pengaruh yang signifikan terhadap perilaku penjual diterima karena saat konsumen memutuskan untuk menghubungi otomatis akan berinteraksi dengan penjual.

Hipotesis Ketiga yang menyatakan bahwa perilaku penjual memiliki pengaruh yang signifikan terhadap keputusan pembelian ditolak, dikarenakan:

i. Pada hasil penelitian dijelaskan bahwa banyak yang melakukan chatting dengan penjual, tetapi hal tersebut tidak bisa memberikan jaminan pembeli untuk memutuskan membeli barang di toko tersebut, hal ini dikarenakan bahwa marketplace merupakan kumpulan dari toko-toko yang memungkinkan memiliki produk yang sama, sehingga konsumen masih memiliki peluang untuk mencari produk sejenis dengan harga yang termurah terlebih dahulu sebelum memutuskan untuk membeli di toko yang telah dihubungi. Sementara penelitian sebelumnya membahas produk skincare, dimana prilaku penjual sangat membantu dalam mencari solusi yang tepat permasalahan kulit konsumen apalagi jika mereka dibekali dengan pengeathuan produk skincare yang mumpuni akan mudah sekalli mempengaruhi konsumen untuk meembeli[4].

ii. Lokasi toko menjadi salah satu alasan pembeli untuk mengurungkan niatnya untuk membeli produk pada sebuah toko, meskipun sebelumnya telah bernegosiasi dan melakukan verifikasi produk dengan penjual.

iii. Beberapa E-commerce tidak menyediakan expedisi cargo, sehingga untuk pembelian dalam jumlah besar, pembeli menjadi terkendala ongkos kirim.

Hipotesis Keempat Live chat berpengaruh signifikan terhadap keputusan pembelian dengan perilaku penjual sebagai variabel mediasi otomatis ditolak karena variabel independen dan variabel mediasinya tidak memiliki pengaruh yang signifikan terhadap variabel dependent, otomatis variabel mediasi tidak berfungsi.

Hipotesis Kelima E-WOM memiliki pengaruh yang signifikan terhadap keputusan pembelian, karena ulasan dari penjual sebelumnya dapat memberikan gambaran kepada calon pembeli terkait integritas toko dan produk yang dijualnya, apalagi jika dilampirkan dengan foto barang yang telah diterima oleh pembeli sebelumnya akan menumbuhkan rasa percaya calon pembeli.

Hipotesis Keenam E-WOM memiliki pengaruh yang signifikan terhadap kelompok Rujukan, hal ini disebabkan karena setelah melihat review konsumen sebelumnya, tentunya konsumen mulai tertarik dengan mengetahui lebih dalam tentang produk tersebut. Sehingga mereka akan berkunjung ke laman produk dan melihat laman produk secara detail termasuk memperhatikan foto atau video dari selebgram yang sedang menggunakan produk tersebut.

Hipotesis Ketujuh Kelompok Rujukan memiliki pengaruh yang signifikan terhadap keputusan pembelian hal ini dapat disebakan oleh budaya masyarakat yang suka meniru gaya para selebgram/artis sehingga muncul keinginkan untuk membeli produk yang di-endorse oleh mereka[14]. Tidak hanya terbatas kepada pengaruh orang-orang terdekat saja [5]

Hipotesis Kedelapan E-WOM berpengaruh terhadap keputusan pembelian dengan kelompok rujukan sebagai variabel mediasi dan efek dari dari variabel mediasi pada hubungan ini bersifat partial karena pengaruh langsung dan tidak langsung bernilai signifikan. Sehingga dengan memanfaatkan jasa selebgram dapat menambah pengaruh review konsumen sebelumnya terhadap calon pembeli untuk memutuskan mebeli produk yang di tawarkan

\section{KESIMPULAN}

Berdasarkan penelitian yang telah dilakukan mengenai hubungan anatara Live chat, perilaku penjual, E-WOM, kelompok rujukan terhadap keputusan pembelian dapat diambil kesimpulan bahwa Live chat dan perilaku penjual tidak berpengaruh signifikan terhadap keputusan pembelian berbeda dengan penelitian sebelumnya (Ref [10]) hal ini dapat disebabkan karena perbedaan karakter produk yang dijual. Pada penelitian sebelumnya yang dijual adalah produk kecantikan, dimana produk ini memiliki efek yang berbeda untuk setiap jenis kulit, sehingga pembeli pembeli akan cendrung melakukan konsultasi terlebih sebelum melakukan pembelian barang. Sementara karakter produk fashion bersifat unik, terbatas dan fast moving sehingga pembeli jarang berinteraksi dengan penjual sebelum melakukan pembelian.

Review dari pembeli sebelumnya juga mampu mempengaruhi konsumen untuk membeli produk tersebut. Pembeli lebih percaya dengan komentar dari pembeli sebelumnya, apalagi jika review menampilkan foto barang asli yang telah diterima oleh pembeli sebelumnya, sehingga calon pembeli memperolah gambaran terhadap produk yang dijual seperti bahan, model, warna, kejujuran penjual dan sebagainya. Untuk dapat memaksimalkan review, maka pengelola situs marketplace dapat memberikan beberapa kebijakan seperti memberikan point reward bagi pembeli yang membuat review terhadap barang yang terakhir dia beli, mengaktifkan notifikasi atau mengeluarkan kebijakan bahwa pembeli dapat melakukan pembelian kembali jika telah membuat review terhadap produk yang dibeli sebelumnya. Sementara dari pihak seller dapat dengan aktif menghubungi pembeli untuk mengisi review terhadap produk yang dia jual.

Banyaknya para selebgram yang bermunculan dengan jumlah pengikut yang cukup banyak di sosial media menjadikan mereka berpotensi untuk menjadi partner dalam mengiklankan produk yang ingin dipasarkan apalagi ditampilkan dalam konten yang cukup menarik akan lebih berpengaruh untuk konsumen dalam mengambil 
keputusan untuk membeli produk yang dipasarkan. Sehingga seller harus mampu melakukan kajian terlebih dahulu siapa selebgram memiliki self branding yang baik, mampu menginterprestasikan produk yang dijual secara sempurna sehingga efek negatif dari penggunaan selebgram tersebut dapat diminimalisir.

\section{DAFTAR PUSTAKA}

[1] Admin, "Lazada, e-Commerce Paling Banyak Pengunjung TW I 2018" , Internet: https://Databoks.Katadata.Co.Id/Datapublish/2018/04/18/Laz ada-E-Commerce-Paling-Banyak-Pengunjung-Tw-I-2018, 18 Apr. 2018 [7 Sept. 2018]

[2] A. Librianty, "5 Prediksi Tren E-Commerce Di Indonesia Pada $2018 "$ Internet: https://www.Liputan6.Com/Tekno/\%20Read/3230715/5Prediksi-Tren-E-Commerce-Di-Indonesia-Pada-2018, 19 Jan. 2018[7 Sept. 2018]

[3] F. Rahman" Strategi UMKM Dalam Membangun Brand Toko Online Di Marketplace “Jurnal Administrasi Bisnis, vol. 53, no. 1,2017

[4] Lv. Zhepeng, "How Do Sellers Use Live Chat To Influence Consumer Purchase Decision In China?"Electronic Commerce Research And Application, vol 28, pp. 102 - 113, 2018

[5] Tan, X., Wang, Y., Tan, Y., "The value of live chat on online purchase."in:Proceedings of the 37th International Conference on Information Systems, 2016.

[6] L.Kang, X. Wang, C-h. Tan \& J. L. Zhao,"Understanding the Antecedents and Consequences of Live Chat Use in Electronic Markets", Journal of Organizational Computing and Electronic Commerce, vol. 25, no. 2, pp.117-139, 2015.

[7] J. Mero (Järvinen), "The effects of two-way communication and chat service usage on consumer attitudes in the ecommerce retailing sector", Electronic Markets, vol. 28 no. 2. pp $205-217,2018$.

[8] G.McLean and K. Osei-Frimpong, "Examining satisfaction with the experience during a live chat service encounterimplications for website providers."Computers in Human Behavior, vol. 76, pp.494-508.2017.

[9] K. Philip dan K. Keller, Manajemen Pemasaran. Edisi 13. Jakarta: Gramedia.

[10] J.J. Wang, "Understanding the effects of eWOM social ties on purchase intentions: A moderated mediation investigation", Electronic Commerce Research And Application, Vol. 28, pp. $54-62,2018$.

[11] H. Zhang, L. Zhao, and S. Gupta, "The role of online product recommendations on customer decision making and loyalty in social shopping communities."International Journal of Information Management, vol. 38 no. 1, pp.150-166.2017.

[12] T. Hennig-Thurau, K.P. Gwinner, G. Walsh, and D.D. Gremler, "Electronic wordof-mouth via consumer-opinion platforms: what motivates consumers to articulate themselves on the Internet."J. Interact. Mark.vol. 18 no. 1, pp. 3852.2017 .
[13] D.J. Bosman, B. Christo, and G. J. van Rooyen. "The review credibility of electronic word-of-mouth communication on ecommerce platforms." Management Dynamics: Journal of the Southern African Institute for Management Scientists, vol. 22. no. 3, pp. 29-44, 2013

[14] A. Larasati, "Pengaruh Gaya Hidup Dan Kelompok Rujukan Terhadap Keputusan Pembelian Tablet Pc Di Kota Denpasar “, E-Jurnal Manajemen, vol. 2, 2012

[15] D. Farela, G. S. Darma "Celebrity Endorser, Daya Tarik Iklan, Brand Awareness Dan Brand Attitude" Jurnal Manajemen Dan Bisnis, vol. 11, no. 1, pp. 35 - 47, 2014

[16] J. Henseler, C. M.Ringland R.R. Sinkovics,” The Use of Partial Least Squares Path Modeling in International Marketing, in Sinkovics, R. R., Ghauri, P. N. (ed.) New Challenges to International Marketing", Advances in International Marketing,vol. 20pp.277 - 319, 2009

\section{BIODATA PENULIS}

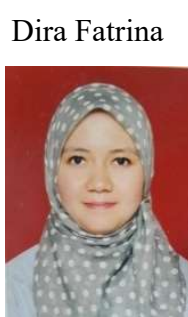

Dira Fatrina lahir di Bukittinggi, Indonesia. Menyelesaikan pendidikan Sarjana Teknik di Jurusan Teknik Industri Fakultas Teknik Universitas Andalas. Memiliki pengalaman bekerja di bidang keuangan di salah satu Bank BUMN. Tertarik pada bidang manajemen keuangan dan bisnis online.

Insannul Kamil

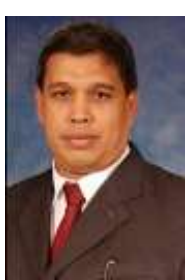

Saat ini menjabat sebagai Dekan Fakultas Teknik Universitas Andalas. Memperoleh gelar Doktor di bidang Teknologi Managemen dari Universiti Teknologi Malaysia. Sebelumnya menyelesaikan pendidikan magister di Toyohashi University Of Technology, Jepang. Memiliki minat riset di bidang Facility and Asset Management, Performance Engineering, Geo Information and Real Estate and Sustainable Construction and Infrasructure. Telah mempublikasikan hasil penelitiannya di berbagai jurnal internasional.

Alizar Hasan

Dilahirkan di Solok, Indonesia, merupakan Guru Besar di bidang

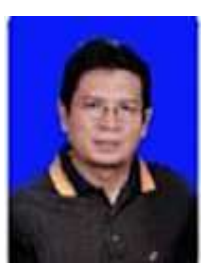
Ilmu Manajemen Industri di Universitas Andalas. Memperoleh gelar Doktor di bidang Teknologi Managemen dari Universiti Sains Malaysia. Sebelumnya menyelesaikan pendidikan magister di ITB dan KU Leuven, Belgia. Memiliki minat riset di bidang Engineering Management dan telah mempublikasikan hasil penelitiannya di berbagai jurnal internasional. 